\title{
SYSTEM OCHRONY ZABYTKÓW ARCHEOLOGICZNYCH. POMIĘDZY TEORIĄ A PRAKTYKĄ KONSERWATORSKĄ
}

KRAWCZEWSKA Agnieszka ${ }^{1}$

${ }^{1}$ Agnieszka Krawczewska, Z-ca Dyrektora Wydziału Powiatowy Konserwator Zabytków Starostwo Powiatowe w Poznaniu

https://orcid.org/0000-0002-5959-5788

ABSTRAKT: Początki konserwatorstwa archeologicznego w Polsce, to przede wszystkim proces identyfikacji zasobu zabytków i jego inwentaryzacja, będące fundamentalnym wyznacznikiem skutecznej ochrony pozostałości dawnej kultury materialnej człowieka.

$\mathrm{W}$ ostatnim czasie pojawienie się $\mathrm{w}$ obszarze nauki nieinwazyjnych metod badań i ich wykorzystywanie w archeologii polskiej spowodowało, że dotychczas przeprowadzana inwentaryzacja źródeł archeologicznych powiązana ze żmudnymi standardowymi badaniami terenowymi, może być szybko i spektakularnie wykonywana. O ile potrzeba dzisiaj stosowania nowoczesnych technik badawczych jest niepodważalna i niezbędna w każdej dyscyplinie naukowej, to za nie mniej ważne uważa się, niepoprzestawanie wyłącznie na etapie pozyskiwania danych, które przyczyniają się do tworzenia bazy obiektów archeologicznych podlegających ochronie, ale nie przynoszą spodziewanej odpowiedzi na postawione pytanie: jak je chronić?

Podczas zabiegów konserwatorskich inwentaryzacji zabytków archeologicznych rodzą się kolejne pytania: gdzie i jakie są czasowe oraz materialne granice ochrony dziedzictwa archeologicznego? Różnorodność zarejestrowanych przykładów reliktów form terenowych począwszy od śladów dawnej orki, poprzez negatywy historycznych obiektów architektury po linie okopów wojennych czy sporządzone wykazy nowożytnych przedmiotów pozyskanych w toku poszukiwań zabytków wymagają od konserwatora podjęcia właściwych decyzji, które nierzadko wzbudzają skrajne reakcje. Czy zatem ochrona zabytków archeologicznych jest sprawnie wypełniana?

Konserwatorstwo archeologiczne winno być postrzegane jako złożony proces składający się z trzech elementów: „inwentaryzacji, ochrony, zarządzania”, gdzie zarządzanie jest rozumiane pod pojęciem długotrwałych programów konserwatorskich opracowanych dla 


\section{Agnieszka Krawczewska}

określonych grup zabytków archeologicznych. Obowiązująca w naszym kraju Ustawa z dnia 23 lipca 2003r. o ochronie zabytków i opiece nad zabytkami umożliwia zastosowanie szeregu efektywnych działań, jednakże aktualny system ochrony zabytków jest nadal skoncentrowany na „inwentaryzacji” i „ochronie”, a trzeci element „zarządzanie” jest wciąż niezwykle trudny w realizacji.

SŁOWA KLUCZE: konserwatorstwo archeologiczne, system ochrony zabytków archeologicznych, urząd ochrony zabytków 
System ochrony zabytków archeologicznych w Polsce jest głównie identyfikowany z działalnością konserwatorską realizowaną przez urzędy ochrony zabytków. Na mocy przepisów prawa, tj. Ustawy z dnia 23 lipca 2003r. o ochronie zabytków i opiece nad zabytkami (t.j. DZ.U.2021.710 ze zm.) zostały określone działania, które podejmuje konserwator w celu ochrony zabytków archeologicznych oraz warunki jakie winien zapewnić właściciel lub posiadacz zabytku podczas sprawowania nad nim opieki. Obraz postrzegania zadań konserwatorskich i sposób ich realizacji ulegał modyfikacji w toku zmieniającej się rzeczywistości oraz kształtowania się stosownych przepisów prawa, w których określone miejsce zajmowały zabytki, a także ludzie mający na nie wpływ.

Poddając analizie system ochrony zabytków archeologicznych w Polsce, można stwierdzić, że pomimo upływającego czasu pewne jego aspekty nie zmieniły się. Wobec powyższego nasuwa się pytanie: czy ten stan rzeczy świadczy o stabilności tego systemu czy wręcz przeciwnie? Niewątpliwie sposób działania konserwatorów zabytków archeologicznych stopniowo reorganizował się począwszy od wymiaru stricte badawczego do sformalizowanego i urzędowego. Dzisiaj trudno wyobrazić sobie, aby inspektorzy zatrudnieni w urzędach ochrony zabytków, tak jak w 1919 roku pierwsi konserwatorzy zabytków archeologicznych skupieni wokół Państwowego Grona Konserwatorów Zabytków Przedhistorycznych, prowadzili w ramach powierzonych im obowiązków służbowych stacjonarne badania wykopaliskowe i interwencyjne badania ratownicze ${ }^{1}$. Ten model pracy charakteryzował działalność Grona Konserwatorów Zabytków Przedhistorycznych.

Po odzyskaniu przez Polskę niepodległości w 1918 roku nastąpiły przemiany ustrojowe, które miały przyczynić się do stabilności Państwa, a także uporządkowania i doprecyzowania wielu przejawów życia społecznego, gospodarczego oraz kulturowego. W zakresie podstawowych czynności zmierzających do podjęcia stosownej ochrony archeologicznych świadectw przeszłości działań ludzkich było rozpoznanie zasobu zabytków i jego zewidencjonowanie. Do tej pory, pomimo znacznego upływu lat są to najbardziej charakterystyczne sposoby działań konserwatorskich kojarzone $z$ ustaleniem stanu zabytków archeologicznych i powiązanej z nimi ochrony. Jednakże nigdy nie zdołamy osiągnąć końcowego etapu, kiedy zbiór zabytków archeologicznych stanie się stałym i zamkniętym zespołem, gdyż zmieniają się uwarunkowania badawcze, możliwości techniczne jego identyfikowania, jak również nasze postrzeganie przeszłości i jej istniejących form, które chcemy chronić. Owe panujące okoliczności wynikają bezpośrednio z samej specyfiki zabytków archeologicznych. Już pierwsza ustawa o ochronie zabytków z 1918 roku - Dekret Rady Regencyjnej o opiece nad zabytkami sztuki i kultury (Dz.U.1918 nr 16 poz. 36) w art. 11 poruszała ten wątek: „Wszelkie nieruchome i ruchome dzieła, świadczące o sztuce i kulturze epok ubiegłych, istniejące nie mniej, niż 50 lat, korzystają z opieki prawa, zanim wpisane zostaną do inwentarza zabytków sztuki i kultury. Korzystają z niej także wszystkie wykopaliska i znaleziska, które z natury rzeczy nie mogą być uprzednio inwentaryzowane. Dzieła ruchome, istniejące mniej niż lat 50, mogą być - w wyjątkowych razach - uznane za zabytki na mocy specjalnej decyzji Ministra W.R. i O.P."

${ }^{1}$ Zakrzewski Z., Sprawozdanie z działalności państw. Urzędu konserwatorskiego na b. dzielnicę pruską, Wiadomości Archeologiczne, VI, 1921, ss. 167-169. 
W odniesieniu do zagadnienia stanu liczebnego nieruchomych zabytków archeologicznych, będzie on stale podlegać zmianie nawet nie na skutek dokonywanych odkryć, ale wykonywanych badań archeologicznych, które spowodują, że dany zabytek zostanie usunięty z krajobrazu na tyle skutecznie, że przestanie być już jego trwałym elementem. Czy oznacza to, że zabytek ten powinien zostać wykreślony z ewidencji zabytków z powodu braku materialnego śladu w otaczającej nas przestrzeni krajobrazu? Na mapie pozostaje tylko "negatyw” substancji archeologicznej i utworzona naukowo-badawcza dokumentacja wraz ze zgromadzonymi przedmiotami - zabytkami ruchomymi towarzyszącymi strukturze nieruchomej. Oznacza to, że dziedzictwem archeologicznym staje się nie zabytek nieruchomy, ale powstała dokumentacyjnobadawcza rzeczywistość, której ramy czasowe nie mają ograniczeń, ponieważ współczesne techniki badawcze mogą doprowadzić do nowych ustaleń, interpretacji i definicji zabytku.

Przez ubiegłe dekad lat, głównym zagrożeniem dla zabytków archeologicznych w Polsce były duże w skali inwestycje budowlane. W historii zagrożeń rodzimego dziedzictwa archeologicznego zapisały się szczególnie budowy kopalń czy gazociągu Jamał i realizacje projektowanych autostrad. Widoczny przełom $\mathrm{w}$ tej kwestii nastąpił w XXI wieku, w wyniku wyzwolenia się intensywnych procesów inwestycyjnych, które doprowadzily do olbrzymiej liczby podejmowanych badań archeologicznych. Pomimo, iż w opracowaniach dotyczących ochrony zabytków archeologicznych wciąż zwraca się baczną uwagę na inwestycje drogowe, jako kluczowe zagrożenie dla dziedzictwa archeologicznego, to analiza wydawanych pozwoleń na prowadzenie badań archeologicznych jednoznacznie wskazuje, że to właśnie budownictwo mieszkaniowe wraz z towarzyszącą infrastrukturą oraz różnorakie inwestycje liniowe najbardziej wpływają na liczbę wykonywanych badań inwazyjnych w terenie.

Można zauważyć, że do niezwykle często pomijanego punktu w rozważaniach na temat ochrony zabytków archeologicznych w kontekście badan archeologicznych podejmowanych w wyniku zagrożenia inwestycyjnego należy istotnie ten najbardziej powszechny rodzaj badań terenowych, który jest jednym $\mathrm{z}$ ostatnich elementów konserwatorskiego procesu ochrony nieruchomego zabytku archeologicznego. Aby doprowadzić do rozpoczęcia badań archeologicznych konserwator zabytków włącza się $\mathrm{w}$ tryb procedury i dokonuje szereg działań na etapie powiązanym z planowaniem przestrzennym. Należy mieć na uwadze fakt, że nie występują takie sytuacje, w których bez wyraźnego nakazu inwestor przystąpi do badań archeologicznych (nie chodzi tutaj o rodzaj decyzji administracyjnej, ale uwarunkowania sformułowane na poziomie różnych dokumentów planistycznych). Natomiast badania archeologiczne podejmowane wyłącznie w celach naukowowo-badawczych (nie pod presją inwestycyjną) stanowią znikomy procent wszystkich przeprowadzanych badan archeologicznych w Polsce. „W warunkach rzeczywistej demokracji (rygorystyczne przestrzeganie procedur) i pełnego poszanowania prawa własności konserwatorzy muszą przekonywać właścicieli zabytków do spełnienia wymagań konserwatorskich. Tym bardziej, że to właściciele finansują prace. Do działania w takich warunkach konserwatorzy nie są przygotowani, dlatego ich rola sprowadza się do opiniowania pomysłów inwestorskich (dotyczy to nawet najwartościowszych obiektów wpisanych na Listę Światowego Dziedzictwa UNESCO). W rezultacie służby konserwatorskie nie kreują aktywnej 
polityki w stosunku do zabytkowego zasobu”2. Przywołane zdanie pochodzące $\mathrm{z}$ „Raportu na temat funkcjonowania systemu ochrony dziedzictwa kulturowego w Polsce po roku 1989" jest twierdzeniem w części o tyle prawdziwym, iż możliwości jakie powstały w dziedzinie życia gospodarczego doprowadzały do lawinowego wzrostu „pomysłów inwestorskich” nadsyłanych do urzędów ochrony zabytków, które konserwator zabytków zobowiązany jest rozpatrzyć, wydając rocznie tysiące opinii, uzgodnień, a w dalszej perspektywie także pozwoleń np. na prowadzenie badań archeologicznych.

$\mathrm{Na}$ podstawie poczynionych refleksji można wysnuć wniosek, że: ochrona nieruchomych zabytków archeologicznych jest $\mathrm{w}$ głównej mierze ochroną o charterze ratowniczym bez mechanizmów zakładających długotrwałą konserwację. W obliczu zagrożenia inwestycyjnego ten rzeczony „kompromis”, okazuje się podstawową zasadą ochrony zabytków archeologicznych. Powyższa konstatacja nie ma na celu wykazania słabości systemu ochrony zabytków archeologicznych, lecz wyraźne podkreślenie, że swoista „wina” za taki, a nie inny stan rzeczy leży w samej naturze zabytków archeologicznych. Oczywistym faktem jest, iż nie można ochronić wszystkich zabytków archeologicznych, gdyż wszelkie podyktowane zakazy doprowadziłyby do całkowitego paraliżu rozwoju gospodarczego. Z jednej strony następuje pewien rodzaj "pogodzenia” się z tym praktykowanym sposobem ochrony (niezależnie od skali, zakresu czy też powagi badań), a z drugiej strony zachodzi automatyczny proces wartościowania zabytków archeologicznych. Dzieje się tak dlatego, ponieważ na drugim końcu zbioru zabytków archeologicznych "chronionych” przez wymuszony proces badawczy są zabytki archeologiczne, które staraniem konserwatora zabytków zostaną wykluczone spod wszelkiej ingerencji. Ostatecznie to konserwator zabytków wypracowuje model ochrony dla danego stanowiska archeologicznego i w toku dalszych działań administracyjnych jest on zobowiązany do jego monitorowania. Użycie odpowiednich mechanizmów nie należy do prostych zadań. Wdrożone działania i osiągane rezultaty nie są łatwo dostrzegalne, tak jak ma to miejsce w przypadku spektakularnych prac zabezpieczających, przywracających świetność zabytkom architektury.

Stanowisko archeologiczne objęte wpisem do rejestru zabytków zlokalizowane na obszarze łąki/ pola/nieużytku nie znajduje atrakcyjnej formy konserwacji i nadal pozostaje jedynie łąką/polem/ nieużytkiem. Wyłączenie stanowiska archeologicznego z gospodarki rolnej jest jedynie eliminacją fizycznej ingerencji człowieka w struktury zabytku. W kolejnej odsłonie, będącej następstwem wspomnianej eliminacji czynnika ludzkiego konserwator zabytków trafia na problem aneksji roślinnej. Zagadnienie to dotyczy także stanowisk archeologicznych zlokalizowanych w strefach lasu. Wydaje się, że nadszedł właśnie oczekiwany moment w działaniach na rzecz ochrony zabytków archeologicznych, aby wspólnie ze specjalistami z dziedziny ochrony środowiska i przyrody podjąć poruszane zagadnienia i opracować szereg niezbędnych wariantów rozwiązań.

${ }^{2}$ Purchla J.(red.), Raport na temat funkcjonowania systemu ochrony dziedzictwa kulturowego w Polsce po roku 1989, 2008, [dostęp: 19.12.2021] https://www.nck.pl/badania/raporty/system-ochronydziedzictwa-kulturowego-w-polsce- 
Oprócz standardowych archeologicznych badań powierzchniowych, badań wykopaliskowych czy przypadkowo dokonywanych odkryć są wykorzystywane metody badań nieinwazyjnych, które pozwalają spojrzeć na nurtującą nas przestrzeń w szerszym zakresie i bez poddawania jej destrukcyjnej mechanicznej ingerencji. Ta trwająca rewolucja powoduje, iżstworzeniejednolitego katalogu form, które „przechowuje” ziemia jest zadaniem prawie niemożliwym do spełnienia, ponieważ nadal nie posiadamy takich narzędzi badawczych, które pomogą nam w sprawnym udzieleniu odpowiedzi na jeszcze wiele pytań. Posiadana świadomość niewyczerpania wiedzy o strukturach przeszłości skutkuje nieustanną „,chęcią odkrywania”, która już nie spoczywa tylko i wyłącznie w polu zainteresowania profesjonalnych badaczy. Należy przy tym zaakcentować, że wszelkie pozostałości, które skrywa ziemia są interpretowane przeważnie w kontekście nauki archeologii. „Można więc przyjąć, że linią „demarkacyjną” archeologii w stosunku do innych zabytków wchodzących w obręb dziedzictwa kultury jest poziom ziemi (także pokrywającej obiekty tworzące własne formy krajobrazowe), po której stąpamy, a to, co może być przedmiotem ochrony z punktu widzenia archeologii występuje poniżej tego poziomu i tak, jak korzenie są trwałymi częściami roślin, tak warstwy podziemne, zawierające pozostałości materialne działania człowieka są immanentnym, choć podziemnym ogniwem krajobrazu kulturowego, dostrzeganego nad ziemią." (Konopka, 2011). W tej sytuacji każda inwestycja, której zakres przewiduje ingerencję w strukturę gruntu wymaga konsultacji archeologicznej. Wskutek tego niezależnie czy na danym terenie jest czy też nie ma śladu zabytku archeologicznego inspektorzy pracujący $\mathrm{w}$ urzędach konserwatorskich wydają rocznie kilkaset opinii, przy czym tylko część $\mathrm{z}$ nich dotyczy zabytków archeologicznych. Ten stan rzeczy będzie się pogłębiać, gdyż odpowiada za to specyficzna natura archeologii, dla której trudno ustalić granice zarówno pod względem liczb i form, które będą wymagać ochrony konserwatorskiej. Istnieje przekonanie, iż inwentaryzacja zasobu archeologicznego i określenie jego granic materialnych będzie skutkować wypracowaniem efektywnych form ochrony. Jest to zadanie, które powinno być nieustannie obecne w dziedzinie ochrony zabytków, jednakże wyniki tego zadania nie stanowią determinantu sposobów ochrony. Jeżeli w ślad za projektami mającymi na celu inwentaryzację i weryfikację zasobu nie będą wypracowywane konkretne modele działań ochronnych (nie tylko w sensie administracyjnym, jak dla przykładu wpis do rejestru zabytków), to projekty te, będą tylko automatycznymi rejestratorami nowych danych powtarzanymi bez końca, na tyle, na ile będzie następował rozwój nowoczesnych metod badawczych.

Innymi słowy na system ochrony zabytków składa sięadministracyjna działalnośćkonserwatorska (konserwatorstwo archeologiczne), działalność muzealnicza oraz badawcza instytucji, jak również społeczna inicjatywa i partycypacja. Tym samym nie powinniśmy postrzegać systemu ochrony zabytków wyłącznie w kategorii instytucjonalnej ochrony. Jeśli istotnym ogniwem staje się większy udział społeczeństwa w ochronie zabytków, to są oni częścią tego systemu w niektórych

${ }^{3}$ Konopka M., Raport w sprawie archeologii - podziemnych zabytków dziedzictwa kulturowego, [w:] System ochrony zabytków w Polsce -analiza, diagnoza, propozycje, red. B. Szmygin, Lublin-Warszawa: Polski Komitet Narodowy ICOMOS, Biuro Stołecznego Konserwatora Zabytków Urzędu Miasta Stołecznego Warszawa, Politechnika Lubelska, s011, ss. 75-88. 
jego aspektach, jako równorzędni partnerzy, natomiast w innych sytuacjach jako wykonujący określone obowiązki wynikające $\mathrm{z}$ administracyjnego nakazu. W tym systemie konserwatorstwo archeologiczne jest subdyscypliną, którą definiują specyficzny zakres i autonomiczne przepisy prawa.

Założenia modelu konserwatorstwa archeologicznego mogłyby wspierać się na trzech zasadniczych filarach merytoryczno-technicznych:

1. „inwentaryzacja” - kontynuacja programu AZP w rozszerzonej formule (ewidencjowanie stanowisk=zabytków/krajobrazów kulturowych)ijego weryfikacja wraz $\mathrm{z}$ modyfikacją uwzględniającą wszystkie dostępne metody badawcze, wykonywanie dokumentacji dla stanowisk wpisanych do rejestru zabytków, korelacja wyników badań archeologicznych z zasobem zabytków, inkorporowanie zasobu do systemów identyfikacji przestrzennej, analiza merytoryczna zasobu, włączanie/wyłączanie z ewidencji, przygotowywanie wpisów do rejestru zabytków,

2. „ochrona” - działania o charakterze prawnym i administracyjnym (opiniowanie, uzgadnianie, wydawanie decyzji), czynności inspekcyjne i kontrolne, tworzenie możliwości finansowania prac konserwacyjnych $\mathrm{w}$ stosunku do zabytków archeologicznych,

3. „zarządzanie” - wartościowanie, diagnoza zagrożeń, analiza wpływu zachodzących zjawisk na zabytki archeologiczne (o charakterze naturalnym i w wyniku działalności człowieka), tworzenie modeli rzeczywistej ochrony, programy długoterminowej konserwacji zabytków, administrowanie dokumentacją badawczą wraz zabytkami ruchomymi, magazynowanie, edukacja.

Ten przedłożony zasadniczy podział modelu konserwatorstwa archeologicznego pozwoliłby na delegowanie zadań do konkretnych „sekcji” zespolonych w jednym urzędzie. Konserwator zabytków działający na lokalnym terenie ma pełną wiedzę o procesach zachodzących w obrębie zabytków, co ułatwia jemu podejmowanie skoncentrowanych czynności. Codzienność konserwatorska, to konieczność realizowania wszystkich tych wskazanych elementów jednocześnie, gdzie jedno z zadań nierzadko musi ustąpić miejsca innemu obwarowanemu sztywnymi terminami procesowymi, których przekroczenie wywołuje negatywne skutki nie tylko w sferze samego obiektu zabytkowego, ale również odpowiedzialności urzędniczej. Osoby tworzące służbę konserwatorską są grupą fachowców głęboko zaangażowanych w proces aranżowania należytej ochrony, jak i dialogu społecznego. Szczupłość kadry pracowniczej wobec szerokiego spektrum zadań konserwatorskich jest bolączką nieustanie podnoszoną w różnych gremiach i na wielu forach. Przy czym należy podkreślić, że obowiązujące przepisy prawa dotyczące ochrony zabytków wbrew powszechnie powtarzanym opiniom o jego mankamentach umożliwiają konserwatorowi zabytków podejmowanie realnie efektywnych działań w ochronie zabytków. Przykładem owego stanu rzeczy są badania archeologiczne, które w obecnym czasie i skali są realizowane wobec zagrożeń inwestycyjnych. Nie opracujemy optymalnej ustawy, aby mogła ona przez długie dekady lat odpowiadać na wszystkie pytania konserwatorskie. Jest to 


\section{Agnieszka Krawczewska}

na tyle oczywiste, o ile oczywista jest materia zabytku, której odpowiada ten przepis prawa. Dziedzictwo mimo jego pewnych trwałych elementów jest organizmem żywym. Najlepszym tego potwierdzeniem jest dziedzictwo archeologiczne. Każde odkrycie może spowodować znaczący przełom w postrzeganiu zabytków, a nowoczesne technologie mogą obalać pewne mity o niemożliwości dokonywania określonych działań w obrębie zabytków. Zapewne każdy kolejny dzień może okazać się nieoczekiwanie zaskakującym dla konserwatorów, badaczy, jak i depozytariuszy dziedzictwa kulturowego. Warto mieć tę świadomość, że przepisy prawa wobec zabytków będą stale się dezaktualizować, ponieważ zmianie ulega rzeczywistość, w której tkwią zabytki. Przewidywanie wszystkich wariantów zmian, które mogą mieć miejsce w przyszłości, a w dalszej konsekwencji stosowanie trafnych rozwiązań nie jest w pełni możliwe, gdyż zależy to od szeregu czynników, na które wcześniej i nie zawsze mamy wpływ. 


\section{Bibliografia}

Konopka M., Raport w sprawie archeologii - podziemnych zabytków dziedzictwa kulturowego, [w:] System ochrony zabytków w Polsce -analiza, diagnoza, propozycje, red. B. Szmygin, LublinWarszawa: Polski Komitet Narodowy ICOMOS, Biuro Stołecznego Konserwatora Zabytków Urzędu Miasta Stołecznego Warszawa, Politechnika Lubelska, 2011, ss. 75-88.

Purchla J. (red.), Raport na temat funkcjonowania systemu ochrony dziedzictwa kulturowego w Polsce po roku 1989, 2008, [dostęp: 19.12.2021], https://www.nck.pl/badania/raporty/systemochrony-dziedzictwa-kulturowego-w-polsce-

Zakrzewski Z., Sprawozdanie z działalności państw. Urzędu konserwatorskiego na b. dzielnicę pruską, Wiadomości Archeologiczne, VI, 1921, ss. 167-169.

Dekret Rady Regencyjnej o opiece nad zabytkami sztuki i kultury (Dz.U.1918 nr 16 poz. 36)

Ustawa z dnia 23 lipca 2003 r. o ochronie zabytków i opiece nad zabytkami (t.j. Dz.U.2021.710 ze $\mathrm{zm}$.) 